Article

\title{
Synthesis, Structural Characterization, and Biological Activities of Organically Templated Cobalt Phosphite $\left(\mathrm{H}_{2} \mathrm{DAB}\right)\left[\mathrm{Co}\left(\mathrm{H}_{2} \mathrm{PO}_{3}\right)_{4}\right] \cdot 2 \mathrm{H}_{2} \mathrm{O}$
}

\author{
Najlaa Hamdi ${ }^{1}$, Souad Chaouch ${ }^{1}$, Ivan da Silva ${ }^{2}$ (D), Mohamed Ezahri ${ }^{3}$, Mohammed Lachkar ${ }^{1}$ (D), Rama Alhasan ${ }^{4}$, \\ Ahmad Yaman Abdin ${ }^{4}\left(\mathbb{D}\right.$, Claus Jacob ${ }^{4, *(D)}$ and Brahim El Bali ${ }^{1, *}$
}

\section{check for} updates

Citation: Hamdi, N.; Chaouch, S.; da Silva, I.; Ezahri, M.; Lachkar, M.; Alhasan, R.; Abdin, A.Y.; Jacob, C.; Bali, B.E. Synthesis, Structural Characterization, and Biological Activities of Organically Templated Cobalt Phosphite $\left(\mathrm{H}_{2} \mathrm{DAB}\right)\left[\mathrm{Co}\left(\mathrm{H}_{2} \mathrm{PO}_{3}\right)_{4}\right] \cdot 2 \mathrm{H}_{2} \mathrm{O} . \mathrm{Sci}$ 2022, 4, 5. https://doi.org/10.3390/ sci4010005

Academic Editor: Juraj Gregán̆

Received: 14 November 2021

Accepted: 19 January 2022

Published: 8 February 2022

Publisher's Note: MDPI stays neutral with regard to jurisdictional claims in published maps and institutional affiliations.

Copyright: (C) 2022 by the authors. Licensee MDPI, Basel, Switzerland. This article is an open access article distributed under the terms and conditions of the Creative Commons Attribution (CC BY) license (https:// creativecommons.org/licenses/by/ $4.0 /)$.
1 Engineering Laboratory of Organometallic Molecular Materials and Environment, Faculty of Sciences, University Sidi Mohamed Ben Abdellah, Fez 30000, Morocco; hamdi.najlae@gmail.com (N.H.); chaouch2005@yahoo.fr (S.C.); lachkar.mohammed@gmail.com (M.L.)

2 ISIS Facility, STFC Rutherford Appleton Laboratory, Chilton, Oxfordshire OX11 0QX, UK; ivan.da-silva@stfc.ac.uk

3 Laboratoire Matériaux et Environnement, Faculté des Sciences, Université Ibn Zohr, Agadir 80000, Morocco; m.ezahri@uiz.ac.ma

4 Division of Bioorganic Chemistry, School of Pharmacy, Saarland University, D-66123 Saarbruecken, Germany; s8rralh@stud.uni-saarland.de (R.A.); yaman.abdin@uni-saarland.de (A.Y.A.)

* Correspondence: c.jacob@mx.uni-saarland.de (C.J.); b_elbali@yahoo.com (B.E.B.)

\begin{abstract}
A novel hybrid cobalt phosphite, $\left(\mathrm{H}_{2} \mathrm{DAB}\right)\left[\mathrm{Co}\left(\mathrm{H}_{2} \mathrm{PO}_{3}\right)_{4}\right] 2 \mathrm{H}_{2} \mathrm{O}$, was synthesized by using a slow evaporation method in the presence of cobalt nitrate, phosphorous acid, and 1,4-diaminobutane (DAB $=1,4$-diaminobutane) as a structure-directing agent. Single-crystal X-ray diffraction analysis showed that the compound crystallizes in the triclinic system (space group P-1(n.2)) with the following unit cell parameters $\left(\AA^{\circ}{ }^{\circ}\right) \mathrm{a}=5.4814$ (3), $\mathrm{b}=7.5515$ (4), $\mathrm{c}=10.8548$ (6), $\alpha=88.001$ (4), $\beta=88.707$ (5), $\gamma=85.126$ (5), and $\mathrm{V}=447.33$ (4) $\AA^{3}$. The crystal structure is built up from corner-sharing $\left[\mathrm{CoO}_{6}\right]$ octahedra, forming chains parallel to [001], which are interconnected by $\mathrm{H}_{2} \mathrm{PO}_{3}{ }^{-}$pseudo-tetrahedral units. The diprotonated cations, residing between the parallel chains, interact with the inorganic moiety via hydrogen bonds, thus leading to the formation of the 3D crystal structure. The Fourier transform infrared spectrum showed characteristic bands corresponding to the phosphite group and the organic amine. The thermal behavior of the compound mainly consisted of the loss of its organic moiety and the water molecules. The biological tests exhibited significant activity against Candida albicans and Escherichia coli strains at different concentrations, while less inhibitory activity was pronounced against Staphylococcus epidermidis and Saccharomyces cerevisiae, and in the case of multi-cellular organisms, no activity against the nematode model Steinernema feltiae was detected.
\end{abstract}

Keywords: hybrid phosphite; X-ray crystal structure; FTIR; thermal behavior; biological activities; antimicrobial; micro-organisms

\section{Introduction}

Crystalline metal-organic frameworks (MOFs) are porous materials with promising physicochemical properties and applications [1-7]. The applications of such materials range from chemical catalysis, energy storage, and drug delivery to food preservation, sterilization, and environmental protection [8]. Several successful examples containing varying metals, e.g., $\mathrm{Ag}^{+}, \mathrm{Cu}^{2+}, \mathrm{Co}^{2+}$ and $\mathrm{Zn}^{2+}$, have been investigated [1]. In this context, the class of hybrid phosphite compounds remains an important focus of many materials scientists due to their wide range of structures exhibiting a richness of geometry, dimensionality, and connectivity [9]. Hybrid phosphite compounds have sustained release capability and structural flexibility in combination with other materials $[10,11]$.

Perhaps one of the most appealing characteristics of hybrid organic-inorganic compounds is their enhanced functionality and performance as compared to individual ingre- 
dients [12]. The combination of inorganic and organic motifs has been shown to result in a synergic effect towards the desired application [8]. MOFs containing $\mathrm{Ag}^{+}, \mathrm{Zn}^{2+}$, and $\mathrm{CO}^{2+}$ have been shown to be promising antimicrobial activity [13]. Hence, they can effectively inhibit bacterial and fungal growth in food, pharmaceutical, and cosmetic products [14]. These compounds can be synthesized through different methods one of which is slow evaporation, which is time-consuming, yet produces pure high yields of the compounds and is generally considered simple [15-26]. While silver-based MOFs are indeed effective and stable they remain relatively expensive and unsuitable for application in corrosive conditions $[27,28]$. Comparatively, much fewer Co hybrid compounds are known; they are relatively cheaper and can be applied effectively as antimicrobial agents, especially as they are less toxic when compared with Ag hybrid compounds [10].

Therefore, we opted to synthesize a novel hybrid cobalt phosphite porous compound and evaluate its biological activity against different micro-organisms. In this context, in the present manuscript, we describe the synthesis achieved via slow evaporation, the crystal structure, the spectroscopic characterization achieved via Fourier transform infrared (FTIR) analysis, and the thermal behavior of the new hybrid phosphite $\left(\mathrm{H}_{2} \mathrm{DAB}\right)\left[\mathrm{Co}\left(\mathrm{H}_{2} \mathrm{PO}_{3}\right)_{4}\right] \cdot 2 \mathrm{H}_{2} \mathrm{O}$. Moreover, we also report on the biological activity of the compound against Candida albicans, Escherichia coli, Staphylococcus epidermidis, Saccharomyces cerevisiae, Steinernema feltiae.

\section{Materials and Methods}

\subsection{Materials and Instrumentation}

All reagents were acquired from commercial sources and used without further purification. The infrared spectrum of the compound was recorded on a VERTEX 70 FTIR Spectrometer in the range $4000-400 \mathrm{~cm}^{-1}$ using the ATR technique at $4 \mathrm{~cm}^{-1}$ resolutions. Thermogravimetric analysis (TGA) data were recorded on an SDT-Q600 analyzer from TA Instruments (Eschborn, Germany). The temperature varied from RT to $1273.15 \mathrm{~K}$ at a heating rate of 10degrees per minute. Measurements were carried out on samples in open platinum crucibles under air flow.

\subsection{Synthesis}

Individual crystals of $\left(\mathrm{H}_{2} \mathrm{DAB}\right)\left[\mathrm{Co}\left(\mathrm{H}_{2} \mathrm{PO}_{3}\right)_{4}\right] \cdot 2 \mathrm{H}_{2} \mathrm{O}$ were synthesized under ambient conditions. The reaction mixture of $\mathrm{Co}\left(\mathrm{NO}_{3}\right)_{2} \cdot 6 \mathrm{H}_{2} \mathrm{O}(1 \mathrm{mmol}, 300 \mathrm{mg})$, 1,4-diaminobutane (DAB) $(1.92 \mathrm{mmol}, 170 \mathrm{mg})$, and $\mathrm{H}_{3} \mathrm{PO}_{3}(3.65 \mathrm{mmol}, 300 \mathrm{mg})$ was shaken in distilled water for $6 \mathrm{~h}$ and then left at room temperature to cool. After 2 weeks, hexagonal purple crystals arose on the bottom of the beaker; these were harvested, washed with water-ethanol mixture (80:20), and dried in air.

\subsection{Crystal Structure Determination}

Single-crystal X-ray diffraction measurement was carried out at room temperature using an Agilent Gemini S diffractometer equipped with a CCD detector and molybdenum (Mo) radiation source. Acquired data were processed with the CrysAlisPro software [29]. Using Olex2 [30], the structure was solved with the olex2.solve [31] structure solution program using Charge Flipping and refined with the olex2.refine [31] refinement package using Gauss-Newton minimization. All non-hydrogen atoms were anisotropically refined, and hydrogen atoms were included in the model at calculated positions and refined with a rigid model with their Uiso value fixed at $1.2 \mathrm{Ueq}$ of their parent atoms.

Table 1 reports the crystallographic data and experimental details of data collection and structure refinements. The structural graphics were produced using both DIAMOND program [32] and Mercury [33].

The supplementary materials containing crystal structure and refinement, the full list of bond lengths and angles, and the anisotropic thermal parameters were deposited with the Inorganic Crystal Structure Database, FIZ, Hermann von Helmholtz Platz 1, 76344 Eggen- 
stein Leopoldshafen, Germany; Fax: (+49)-7247-808-132; Email: crysdata@fiz-karlsruhe.de. The deposition number is CCDC 1882579.

Table 1. Experimental X-ray data collection from $\left(\mathrm{H}_{2} \mathrm{DAB}\right)\left[\mathrm{Co}\left(\mathrm{H}_{2} \mathrm{PO}_{3}\right)_{4}\right] \cdot 2 \mathrm{H}_{2} \mathrm{O}$.

\begin{tabular}{|c|c|}
\hline Chemical Formula & $\left(\mathrm{C}_{4} \mathrm{H}_{14} \mathrm{~N}_{2}\right)\left[\mathrm{Co}\left(\mathrm{H}_{2} \mathrm{PO}_{3}\right)_{4}\right] \cdot 2 \mathrm{H}_{2} \mathrm{O}$ \\
\hline $\operatorname{Mr}(\mathrm{g} / \mathrm{mol})$ & 509.08 \\
\hline $\mathrm{F}(000)$ & 263.9 \\
\hline Symmetry, S.G. & Triclinic P-1 (n. 2) \\
\hline Cell parameters/V & $\begin{array}{c}A=5.4814(3) \AA, b=7.5515(4) \AA, c=10.8548(6) \AA \\
\alpha=88.001(4)^{\circ}, \beta=88.707(5)^{\circ}, \gamma=85.126(5)^{\circ} / 447.33(4) \AA^{3}\end{array}$ \\
\hline $\mathrm{Z}$ & 1 \\
\hline$\lambda($ Mo $K \alpha$ radiation) $(\AA)$ & 0.71073 \\
\hline $\mathrm{T}(\mathrm{K}) / \mu\left(\mathrm{mm}^{-1}\right)$ & $298 / 1.39$ \\
\hline Crystal size (mm) & $0.25 \times 0.25 \times 0.3$ \\
\hline $\begin{array}{l}\text { Measured reflections/independent } \\
\text { reflections (reflections with } \mathrm{I} \geq 2 \mathrm{u}(\mathrm{I}) \text { )/ parameters }\end{array}$ & $9480 / 2005(1878) / 137$ \\
\hline$\Theta \min -\theta \max \left({ }^{\circ}\right) / \operatorname{Rint}$ & $1.9-27.8 / 0.024$ \\
\hline Reciprocal space limiting indices & h: $-6-7, \mathrm{k}:-9-9, \mathrm{l}:-13-14$ \\
\hline $\mathrm{R}[\mathrm{F} 2>2 \sigma(\mathrm{F} 2)] / w \mathrm{R}(\mathrm{F} 2) /$ G.O.F. & $0.026 / 0.072 / 1.03$ \\
\hline
\end{tabular}

\subsection{Biological Assays}

\subsubsection{The Antimicrobial Activity}

The activity of $\left(\mathrm{H}_{2} \mathrm{DAB}\right)\left[\mathrm{Co}\left(\mathrm{H}_{2} \mathrm{PO}_{3}\right)_{4}\right] \cdot 2 \mathrm{H}_{2} \mathrm{O}$ compound against. C. albicans, E. coli strains, S. epidermidis, $S$. cerevisiae, and $S$. feltiae. was investigated in routine microbial growth assays based on optical density and recorded in the form of growth curves. Fresh cultures of S. epidermidis, E. coli, C. albicans, and S. cerevisiae were prepared on bacterial tryptic soy broth, Luria-Bertani broth (LB), Sabouraud Dextrose Agar (SDA), and Yeast Peptone Dextrose (YPD) agar media, respectively. After 18-24 h of incubation, the microbial colonies from these agar plates were then transferred into $10 \mathrm{~mL}$ solution of $0.9 \% \mathrm{w} / \mathrm{v} \mathrm{NaCl}$ (saline), and the turbidity of the suspension was adjusted to 0.5 of McFarland standard. These microbial suspensions were then exposed to the samples as described in Section 3.4. Bacterial and yeast culture with growth medium were employed as negative controls and sterile distilled water was utilized as a solvent control, whilst the positive control consisted of a mixture of 10,000 units. $\mathrm{mL}^{-1}$ of penicillin, $10,000 \mu \mathrm{g} . \mathrm{mL}^{-1}$ of streptomycin, and $25 \mu \mathrm{g} . \mathrm{mL}^{-1}$ of amphotericin B. The sample was evaluated at various dilutions (of 250, 500 , and $1000 \mu \mathrm{M}$ ), and the plates were incubated at $37^{\circ} \mathrm{C}$ for $24 \mathrm{~h}$. Microbial growth was monitored by recording the optical density of the samples at $0 \mathrm{~h}$ and $24 \mathrm{~h}$ using a Micro Plate Reader E800 at $593 \mathrm{~nm}$. These absorbance values were converted into percentages and compared to the negative control, whose absorbance values were normalized to $100 \%$ and served as references at each time interval. All experiments were carried out in triplicate at three different occasions $(n=9)$. Results are represented as mean $\pm S D$, and statistical significances were calculated by one-way ANOVA using GraphPad Prism (Version 5.03, GraphPad Software, La Jolla, CA, USA) with $p<0.05$ considered to be of statistical significance.

\subsubsection{Nematocidal Activity}

The model nematode, S. feltiae, was purchased from Sautter und Stepper GmbH (Ammerbuch, Germany) in the form of powder and stored at $4{ }^{\circ} \mathrm{C}$ in the dark. Fresh samples were utilized prior to each experiment. A homogeneous mixture was prepared by dissolving $200 \mathrm{mg}$ of nematode powder in $50 \mathrm{~mL}$ distilled water. Later, the nematode suspension 
was placed for $15 \mathrm{~min}$ at room temperature with shaking and in moderate light. Viability was examined under a light microscope at four-fold magnification (TR 200, VWR International, Leuven, Belgium). The viability of nematodes above $80 \%$ in each sample was considered a prerequisite for each experiment. 10 microliters of nematode suspension was added to each well of a 96-well plate. The hybrid cobalt phosphite $\left(\mathrm{H}_{2} \mathrm{DAB}\right)\left[\mathrm{Co}\left(\mathrm{H}_{2} \mathrm{PO}_{3}\right)_{4}\right] \cdot 2 \mathrm{H}_{2} \mathrm{O}$ was then added into the wells to achieve concentrations of 250, 500 and $1000 \mu \mathrm{M}$. Afterwards, the volume in each well was adjusted to $100 \mu \mathrm{L}$ by adding Phosphate Buffered Saline (PBS pH = 7.4). PBS and ethanol (10 $\mu \mathrm{L}$ per well) were employed as negative and positive controls, respectively, and sterile distilled water was the solvent control. Each experiment was performed independently on three different occasions and in triplicate $(n=9)$. Living and dead nematodes were counted under the microscope prior to treatment, and the viability fraction (V0) was calculated (usually $>0.9$ ). Prior to recounting at $\mathrm{V}_{24}$, $50 \mu \mathrm{L}$ of lukewarm water $\left(40^{\circ} \mathrm{C}\right)$ was added to each well to stimulate the nematodes. The $\mathrm{V}_{24}$ fraction was calculated in terms of living and dead nematodes and was expressed as a percentage of initial viability $\mathrm{V}_{0}$ according to the equation:

$$
\text { Viability }(\%)=\left[\mathrm{V}_{24} / \mathrm{V}_{0}\right] \times 100
$$

Results are represented as mean \pm SD, and GraphPad Prism (Version 5.03, GraphPad Software, La Jolla, CA, USA) was used to calculate the statistical significances by one-way ANOVA. $p<0.05$ was statistically significant.

\section{Results and Discussion}

\subsection{Structural Description}

As shown in Figure 1, there was one crystallographically distinct $\mathrm{Co}$ located at special position $\left(\frac{1}{2} 0 \frac{1}{2}\right)$ (Table 1). The asymmetric unit of $\left(\mathrm{H}_{2} \mathrm{DAB}\right)\left[\mathrm{Co}\left(\mathrm{H}_{2} \mathrm{PO}_{3}\right)_{4}\right] \cdot 2 \mathrm{H}_{2} \mathrm{O}$ contained 13 non-hydrogen atoms located at general positions (Table 1), including one water oxygen named $\mathrm{O}(13)$. The cobalt cation showed octahedral geometry, coordinating six oxygen atoms from adjacent phosphite groups. The $\mathrm{Co}-\mathrm{O}$ bond lengths ranged from 2.0919(12) $\AA$ to 2.1336(12) $\AA$, with an average $\mathrm{Co}-\mathrm{O}$ distance of $2.1258 \AA$, in good agreement with the value $2.113 \AA$ reported in $\left[\left(\mathrm{C}_{4} \mathrm{~N}_{8} \mathrm{H}_{12}\right) \mathrm{Co}\left(\mathrm{HPO}_{3}\right)_{2}\left(\mathrm{C}_{2} \mathrm{O}_{4}\right)_{3}\right]$ [34] and to that of $2.1205 \AA$ for $\left(\mathrm{C}_{2} \mathrm{H}_{10} \mathrm{~N}_{2}\right)\left[\mathrm{Co}_{3}\left(\mathrm{HPO}_{3}\right)_{4}\right]$ [35]. All $\mathrm{H}_{2} \mathrm{PO}_{3}{ }^{-}$units adopted pseudo-tetrahedral coordination geometry. $\mathrm{P}(5)$ shared two oxygens with adjacent $\mathrm{Co}$ atoms, while $\mathrm{P}(7)$ was connected by one $\mathrm{P}-\mathrm{O}-\mathrm{Co}$ bond and possessed a short terminal P-O bond (1.4955 (15) $\AA$ ). The P-O bond distances were in the range 1.5050(13)-1.5732(14) $\AA$ for $\mathrm{P}(5)$ atom $\left[\mathrm{d}_{(\mathrm{P}-\mathrm{O})} \mathrm{Av} .1 .5283 \AA\right]$ and 1.4987(13)-1.5625(15) $\AA$ for $\mathrm{P}(7)\left[\mathrm{d}_{(\mathrm{P}-\mathrm{O})}\right.$ Av. $1.5189 \AA$ ]. $\mathrm{P}(5)$ and $\mathrm{P}(7)$ atoms had a terminal phosphite $\mathrm{P}-\mathrm{H}$ bond 1.241 (1) and 1.3127 (1) $\AA$, respectively. These values are in good agreement with those reported in $\left(\mathrm{C}_{2} \mathrm{NH}_{8}\right)_{2}\left[\mathrm{Co}_{3}\left(\mathrm{HPO}_{3}\right)_{4}\right],\left(\mathrm{C}_{4} \mathrm{~N}_{2} \mathrm{H}_{12}\right)\left[\mathrm{Co}\left(\mathrm{HPO}_{3}\right)_{2}\right]$ [36], and $\left(\mathrm{H}_{2} \mathrm{DAB}\right)_{0.5} \mathrm{Co}\left(\mathrm{H}_{2} \mathrm{PO}_{3}\right)\left(\mathrm{C}_{2} \mathrm{O}_{4}\right)[37]$.

The strict alternation of $\left[\mathrm{CoO}_{6}\right]$ octahedra and $\mathrm{H}_{2} \mathrm{PO}_{3}{ }^{-}$pseudo tetrahedral via oxygen vertices resulted in an anionic network with a $\mathrm{Co} / \mathrm{P}$ ratio of $1 / 2$. The polyhedral units were joined through corners sharing four-membered rings, which were thereby connected through their edges, forming an infinite one-dimensional chain rising along [100], Figure 2.

The individual chain units were further linked together through hydrogen bond interactions (Figure 3, Table 2). The 1,4-butanediammonium templates made up of N12, $\mathrm{C} 11$, and $\mathrm{C} 10$ atoms and their symmetry-related $\mathrm{N} 12^{\mathrm{i}}, \mathrm{C} 11^{\mathrm{i}}$ and $\mathrm{C} 10^{\mathrm{i}}$, which reside between the parallel chains, were deprotonated. Together with the free-standing water molecules, they were further ensuring the stability of the three-dimensional network.

\subsection{Infrared Spectroscopy}

The infrared spectrum of $\left(\mathrm{H}_{2} \mathrm{DAB}\right)\left[\mathrm{Co}\left(\mathrm{H}_{2} \mathrm{PO}_{3}\right)_{4}\right] \cdot 2 \mathrm{H}_{2} \mathrm{O}$ (Figure 4) exhibited bands corresponding to the vibration modes of the organic template, phosphite groups, and water molecules. The stretching vibration of $\mathrm{NH}_{2}$ in 1,4-butanediammonium cation was observed in the high frequencies of $3090-3200 \mathrm{~cm}^{-1}$, while its bending appeared at $1600 \mathrm{~cm}^{-1}$ [38]. 
The values pointing between 2600 and $2736 \mathrm{~cm}^{-1}$ corresponded to the symmetric and asymmetric stretching of $\mathrm{NH}_{3}{ }^{+}$, and also confirmed the protonation form of the organic amine molecule. The two large vibrations at around 2813 and $2923 \mathrm{~cm}^{-1}$ were down to the stretching mode of $v\left(-\mathrm{CH}_{2}-\right)$, while the medium band at $1314 \mathrm{~cm}^{-1}$ coincided with the stretching vibration of $v(\mathrm{C}-\mathrm{N})$. The characteristic bond of phosphite groups was manifested by a small and medium vibration at around 2420 and $2430 \mathrm{~cm}^{-1}$ and it corresponded to the stretching vibration of $v(\mathrm{P}-\mathrm{H})$, while the bands from 990 to $1030 \mathrm{~cm}^{-1}$ were assigned to the bending mode of $\delta(\mathrm{P}-\mathrm{H})$. The vibration modes centered at 1057 and $1164 \mathrm{~cm}^{-1}$ were ascribed to the symmetric and asymmetric stretching of $\mathrm{PO}_{3}$ group, while its symmetric and asymmetric bending were observed at 670 and $460 \mathrm{~cm}^{-1}$, respectively. The broad vibration located at $916 \mathrm{~cm}^{-1}$ was attributed to the stretching vibration of $\mathrm{P}-\mathrm{OH}$ bond [25] The set of bands related to the stretching vibration and deformation of the $\mathrm{OH}$ group and belonging to water molecules was observed at around 3000 and $1645 \mathrm{~cm}^{-1}[19,20]$.

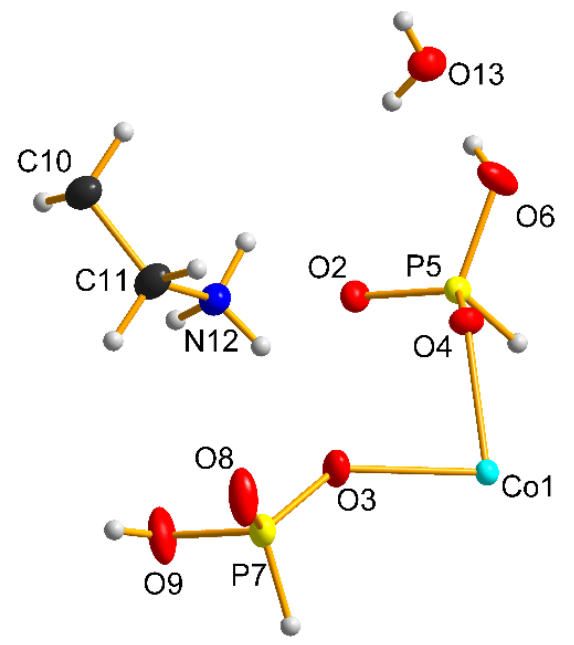

Figure 1. Asymmetric unit of $\left(\mathrm{H}_{2} \mathrm{DAB}\right)\left[\mathrm{Co}\left(\mathrm{H}_{2} \mathrm{PO}_{3}\right)_{4}\right] \cdot 2 \mathrm{H}_{2} \mathrm{O}$. Thermal ellipsoids are shown at $60 \%$ probability.

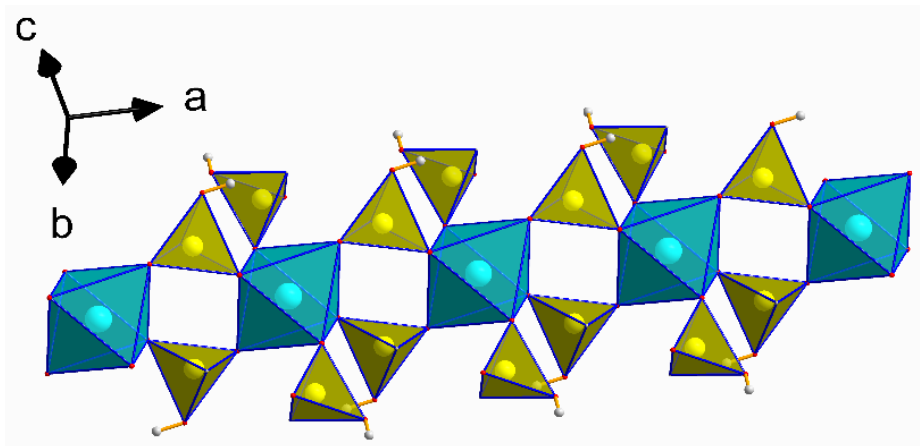

Figure 2. A fragment of the structure of $\left(\mathrm{H}_{2} \mathrm{DAB}\right)\left[\mathrm{Co}\left(\mathrm{H}_{2} \mathrm{PO}_{3}\right)_{4}\right] \cdot 2 \mathrm{H}_{2} \mathrm{O}$ along [010], showing the infinite four-membered ring chain propagating along [100]. Polyhedrons: cyan [CoO6], yellow $\mathrm{H}_{2} \mathrm{PO}_{3}{ }^{-}$.

Table 2. Hydrogen bonding network in the framework of $\left(\mathrm{H}_{2} \mathrm{DAB}\right)\left[\mathrm{Co}\left(\mathrm{H}_{2} \mathrm{PO}_{3}\right)_{4}\right] \cdot 2 \mathrm{H}_{2} \mathrm{O}$.

\begin{tabular}{ccccc}
\hline $\mathbf{D}-\mathbf{H} \cdots \mathbf{A}$ & $\mathbf{D}-\mathbf{H} / \mathbf{A}$ & $\mathbf{H} \cdots \mathbf{A} / \mathbf{A}$ & $\mathbf{D} \cdots \mathbf{A} / \mathbf{A}$ & $\mathbf{D H A} /{ }^{\circ}$ \\
\hline $\mathrm{O} 6-\mathrm{H} 6 \cdots \mathrm{O} 13$ & $0.80(3)$ & $1.80(3)$ & $2.605(2)$ & $175(3)$ \\
$\mathrm{O} 9-\mathrm{H} 9 \cdots \mathrm{O} 8$ & $0.82(1)$ & $1.77(1)$ & $2.574(2)$ & $169(1)$ \\
$\mathrm{N} 12-\mathrm{H} 12 \mathrm{~A} \cdots \mathrm{O} 6$ & $0.89(1)$ & $2.16(1)$ & $2.900(2)$ & $140(1)$ \\
$\mathrm{N} 12-\mathrm{H} 12 \mathrm{~B} \cdots \mathrm{O} 3$ & $0.89(1)$ & $2.02(1)$ & $2.887(2)$ & $166(1)$ \\
$\mathrm{N} 12-\mathrm{H} 12 \mathrm{C} \cdots \mathrm{O} 8$ & $0.89(1)$ & $1.91(1)$ & $2.776(2)$ & $165(1)$ \\
$\mathrm{O} 13-\mathrm{H} 13 \mathrm{~A} \cdots \mathrm{O} 2$ & $0.71(3)$ & $2.22(3)$ & $2.888(2)$ & $159(3)$ \\
$\mathrm{O} 13-\mathrm{H} 13 \mathrm{~B} \cdots \mathrm{O} 4$ & $0.76(3)$ & $2.11(3)$ & $2.863(2)$ & $179(4)$ \\
\hline
\end{tabular}




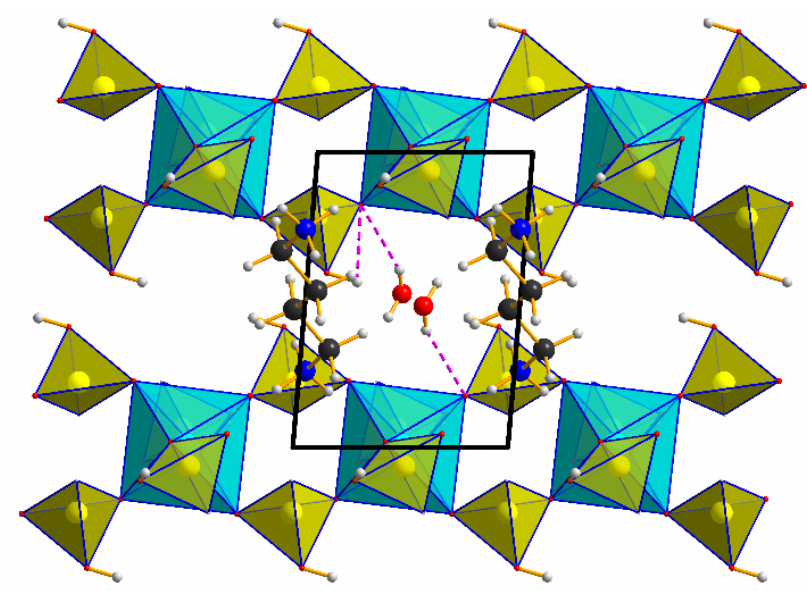

Figure 3. The crystal structure of $\left(\mathrm{H}_{2} \mathrm{DAB}\right)\left[\mathrm{Co}\left(\mathrm{H}_{2} \mathrm{PO}_{3}\right)_{4}\right] \cdot 2 \mathrm{H}_{2} \mathrm{O}$ in a projection along c-axis emphasizing the hydrogen bonds (dashed lines).

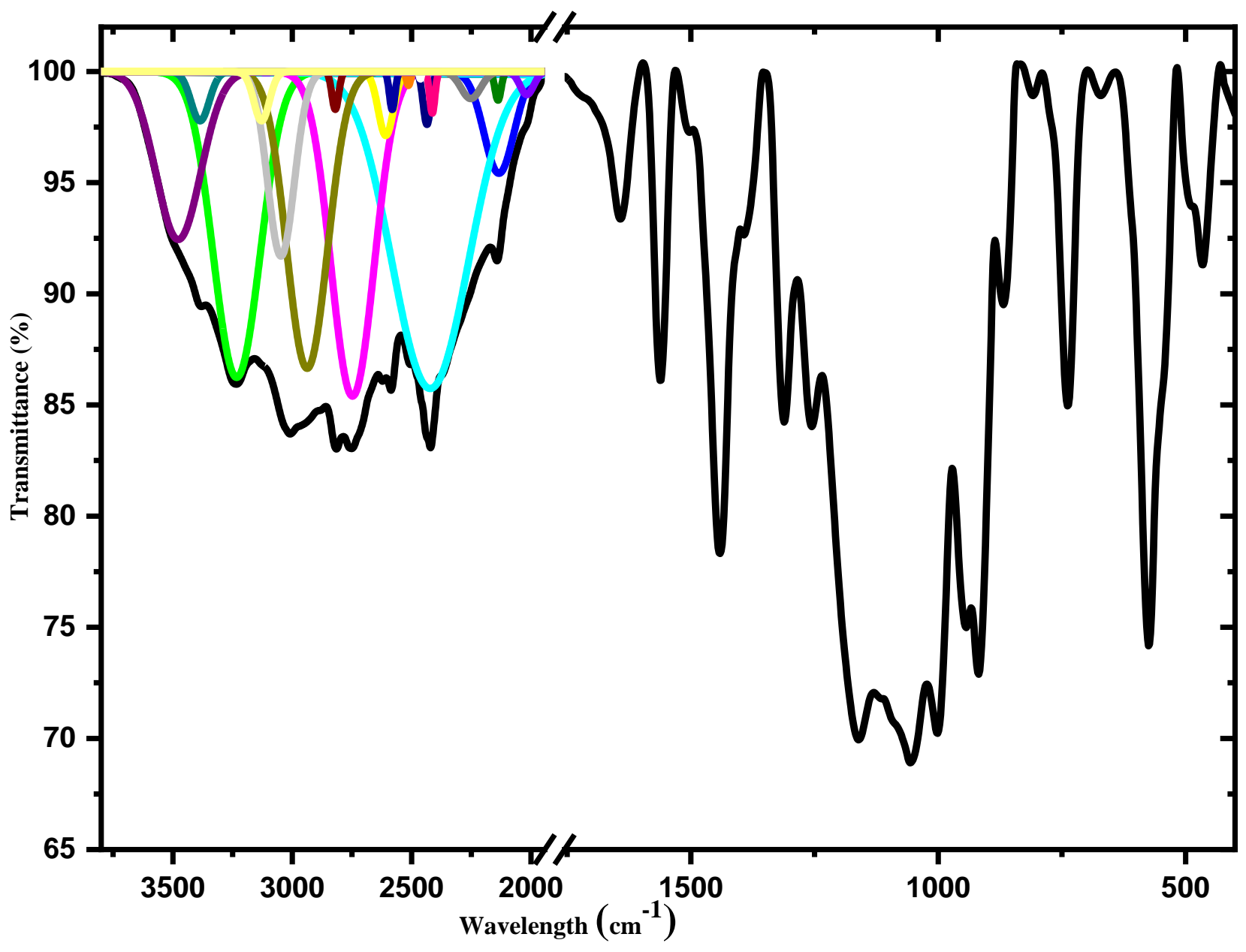

Figure 4. Infrared spectrum of $\left(\mathrm{H}_{2} \mathrm{DAB}\right)\left[\mathrm{Co}\left(\mathrm{H}_{2} \mathrm{PO}_{3}\right)_{4}\right] \cdot 2 \mathrm{H}_{2} \mathrm{O}$.

\subsection{Thermal Behavior}

Thermal analysis was performed under air atmosphere, and as depicted in Figure 5, the experimental data of $\left(\mathrm{H}_{2} \mathrm{DAB}\right)\left[\mathrm{Co}\left(\mathrm{H}_{2} \mathrm{PO}_{3}\right)_{4}\right] \cdot 2 \mathrm{H}_{2} \mathrm{O}$ showed four separated stages of weight loss in a total of $52.75 \%$ ranging from 25 to $1000{ }^{\circ} \mathrm{C}$. The first experimental mass loss (5.45\%) occurred between 150 and $270{ }^{\circ} \mathrm{C}$ and corresponded to the easy departure of one and half molecules of the two structural water molecules (calculated value $5.30 \%$ ). This quick dehydration of the hybrid cobalt phosphite may be explained by the engagement of 
the water molecules in a weak network of hydrogen bonds. This variation was coupled with a sharp exothermic signal in the differential thermal analysis trace at $174{ }^{\circ} \mathrm{C}$. The second weight loss of $5.35 \%$, ranging from 271 to $358{ }^{\circ} \mathrm{C}$ on the TG curve, was related to the departure of the remaining half water molecule and the release of $\mathrm{NH}_{3}$ unit from the organic moiety (calculated value $5.11 \%$ ). This degradation was manifested by an intense exothermic peak at $292{ }^{\circ} \mathrm{C}$. The experimental value of $8.95 \%$, pointing at $385{ }^{\circ} \mathrm{C}$ on the TG profile and highlighted by a small set of signals on the DTA measurement, coincided with the continuous volatilization of the organic moiety (calculated value $8.85 \%$ ). The last experimental mass loss (33\%), observed between 497 and $973{ }^{\circ} \mathrm{C}$ can be associated with the total degradation of the organic moiety and the formation of the cobalt metaphosphate compound $\mathrm{Co}\left(\mathrm{PO}_{3}\right)_{2}$ through a condensation reaction of phosphite groups (calculated value $37 \%$ ). This formation was mainly characterized by a small exothermic heat flow at $632{ }^{\circ} \mathrm{C}$.

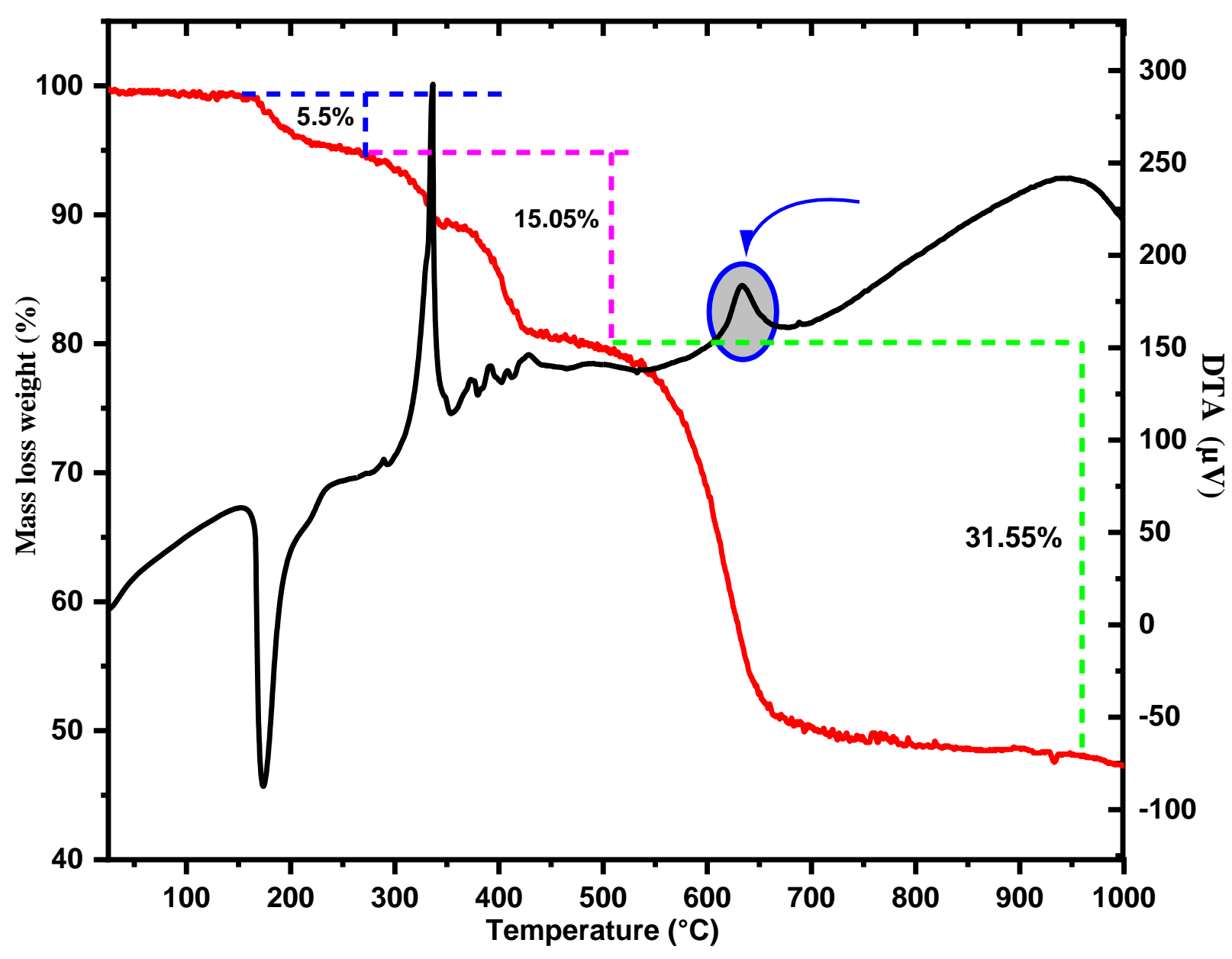

Figure 5. Thermogravimetric (TG) and differential thermal analysis (TDA) curves of $\left(\mathrm{H}_{2} \mathrm{DAB}\right)\left[\mathrm{Co}\left(\mathrm{H}_{2} \mathrm{PO}_{3}\right)_{4}\right] \cdot 2 \mathrm{H}_{2} \mathrm{O}$.

\subsection{Biological Activities}

The hybrid cobalt phosphite compound was tested for its antimicrobial activity against two bacteria (E. coli and S. epidermidis) and two fungi (S. cerevisiae and C. albicans) strains. A mixture of 10,000 units. $\mathrm{mL}^{-1}$ of penicillin, $10,000 \mu \mathrm{g} . \mathrm{mL}^{-1}$ of streptomycin, and $25 \mu \mathrm{g} . \mathrm{mL}^{-1}$ of amphotericin B was used as a control at three different concentrations, 250, 500 and $1000 \mu \mathrm{g} . \mathrm{mL}^{-1}$. Ethanol was used as a positive control. The percentage inhibition and minimum inhibitory concentration (MIC) values of the compound based on the growth of micro-organisms are shown in Figure 6. 

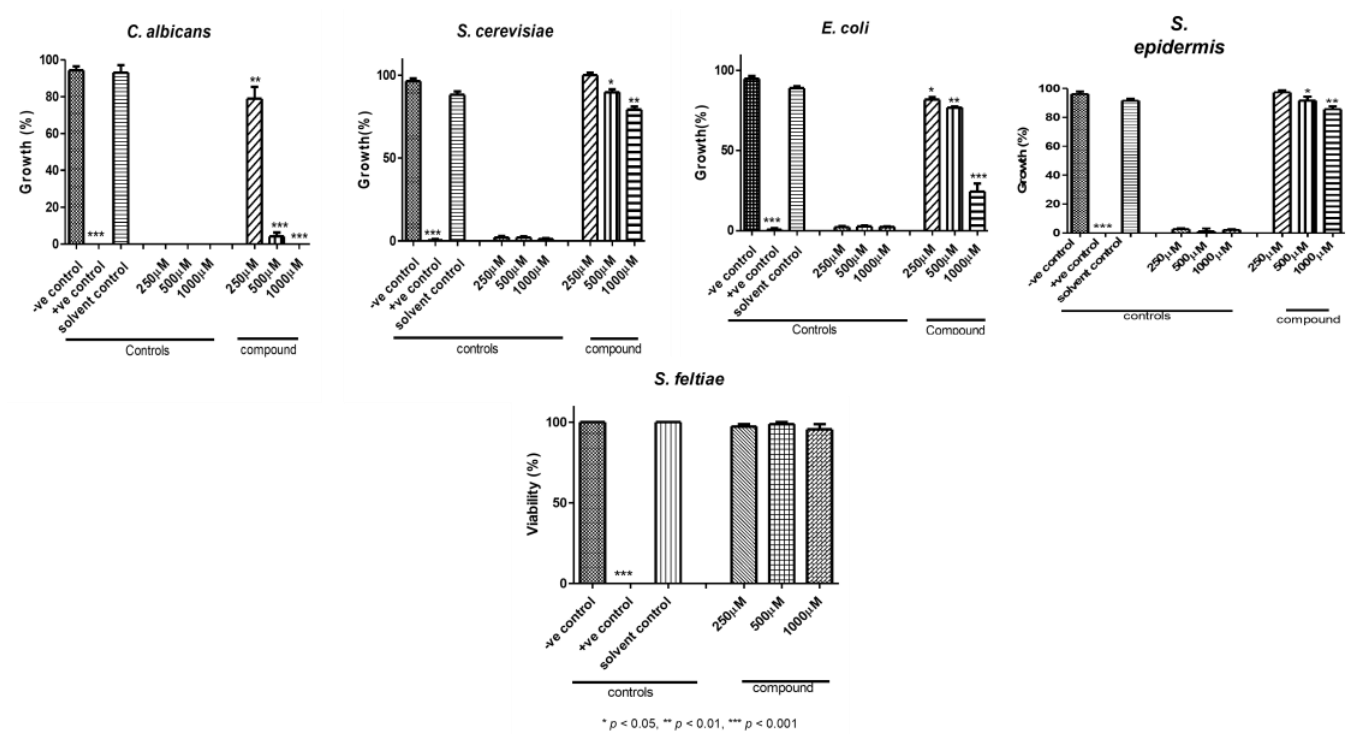

Figure 6. Antimicrobial activity of $\left(\mathrm{H}_{2} \mathrm{DAB}\right)\left[\mathrm{Co}\left(\mathrm{H}_{2} \mathrm{PO}_{3}\right)_{4}\right] \cdot 2 \mathrm{H}_{2} \mathrm{O}$ against $C$. albicans, $S$. cerevisiae, E. coli, S. epidermidis and S. feltiae.

The mechanism of action attributed to the antimicrobial activity of MOFs resides in their metal-ion reservoir and their controlled degradation and release of the soft metal ions from the hard organic ligands $[38,39]$. Several MOFs containing silver and copper have been investigated extensively and shown to have significant antibacterial antiviral and antifungal activities [40-43]. Cobalt phosphite MOFs are stable in water and more affordable [44-47]. These Co compounds are believed to affect micro-organisms through two main mechanisms: (1) the release of $\mathrm{Co}^{2+}$ ions, similar to silver and copper compounds and (2) the direct interaction between the $\mathrm{Co}^{2+}$ with the microbial cellular membrane [47-52].

Statistically, our hybrid cobalt phosphite compound exhibited significant inhibitory activity against $C$. albicans, E. coli strains, S. epidermidis and S. cerevisiae, and but not against the multi-cellular organism $S$. feltiae. In terms of growth reduction observed, the hybrid cobalt phosphite compound demonstrated strong antifungal activity against C. albicans at an MIC value of 500 and $1000 \mu \mathrm{g} \cdot \mathrm{mL}^{-1}$. Notably, the inhibition of growth was much less in the case of $S$. cerevisiae. The compound showed lower activity as an antibacterial agent. Here, E. coli demonstrated higher inhibition than S. epidermidis. The nematode assay showed that the compound had almost no impact on viability against this organism.

\section{Conclusions}

A novel organically templated cobalt phosphite $\left(\mathrm{H}_{2} \mathrm{DAB}\right)\left[\mathrm{Co}\left(\mathrm{H}_{2} \mathrm{PO}_{3}\right)_{4}\right] \cdot 2 \mathrm{H}_{2} \mathrm{O}$ was synthesized by slow evaporation. Single-crystal structure analysis showed that the framework displays a chain-like structure, containing vertex-sharing four-membered rings formed by the connectivity between $\left[\mathrm{CoO}_{6}\right]$ octahedrons and $\left[\mathrm{H}_{2} \mathrm{PO}_{3}\right]$-pseudo-tetrahedral units bound through their edges. The 1,4-butanediammonium acts as a stabilizer of the inorganic network through hydrogen bonds. The thermogravimetric analysis showed that the dehydration of the hybrid phosphite takes place in three steps, resulting mainly from the loss of the organic moiety and water molecules. The antimicrobial investigation exhibited significant activity against C. albicans and E. coli strains, while less activity was noted against S.cerevisiae and S. epidermidis. Further studies on hybrid phosphite compounds are needed to assess their safety and applicability in the fields of medicine and agriculture. More studies should also focus on comparing the utility gain between cobalt, copper, zinc, and silver MOFs.

Supplementary Materials: The following are available online at https:/ /www.mdpi.com/article/10 $.3390 /$ sci4010005/s1, Figure S1. Asymmetric unit of $\left(\mathrm{H}_{2} \mathrm{DAB}\right)\left[\mathrm{Co}\left(\mathrm{H}_{2} \mathrm{PO}_{3}\right)_{4}\right] \cdot 2 \mathrm{H}_{2} \mathrm{O}$. Thermal ellipsoids are shown at $60 \%$ probability. Figure S2. A fragment of the structure of $\left(\mathrm{H}_{2} \mathrm{DAB}\right)\left[\mathrm{Co}\left(\mathrm{H}_{2} \mathrm{PO}_{3}\right)_{4}\right] \cdot 2 \mathrm{H} 2 \mathrm{O}$ 
along [010], showing the infinite four-membered ring chain propagating along [100]. Polyhedrons: cyan $\left[\mathrm{CoO}_{6}\right]$, yellow $\left[\mathrm{H}_{2} \mathrm{PO}_{3}\right]$. Figure S3. The crystal structure of $\left(\mathrm{H}_{2} \mathrm{DAB}\right)\left[\mathrm{Co}\left(\mathrm{H}_{2} \mathrm{PO}_{3}\right)_{4}\right] \cdot 2 \mathrm{H}_{2} \mathrm{O}$ in a projection along c-axis emphasizing the hydrogen bonds (dashed lines). Figure S4. Infrared spectrum of $\left(\mathrm{H}_{2} \mathrm{DAB}\right)\left[\mathrm{Co}\left(\mathrm{H}_{2} \mathrm{PO}_{3}\right)_{4}\right] \cdot 2 \mathrm{H}_{2} \mathrm{O}$. Figure S5. Thermogravimetric (TG) and differential thermal analysis (TDA) curves of $\left(\mathrm{H}_{2} \mathrm{DAB}\right)\left[\mathrm{Co}\left(\mathrm{H}_{2} \mathrm{PO}_{3}\right)_{4}\right] \cdot 2 \mathrm{H}_{2} \mathrm{O}$. Figure S6. Antimicrobial activity of $\left(\mathrm{H}_{2} \mathrm{DAB}\right)\left[\mathrm{Co}\left(\mathrm{H}_{2} \mathrm{PO}_{3}\right)_{4}\right] \cdot 2 \mathrm{H}_{2} \mathrm{O}$ against Candida albicans, Saccharomyces cerevisiae, Escherichia coli, Staphylococcus epidermidis and Steinernema feltiae. Table S1. Experimental X-ray data collection from $\left(\mathrm{H}_{2} \mathrm{DAB}\right)\left[\mathrm{Co}\left(\mathrm{H}_{2} \mathrm{PO}_{3}\right)_{4}\right] \cdot 2 \mathrm{H}_{2} \mathrm{O}$. Table S2. Hydrogen bonding network in the framework of $\left(\mathrm{H}_{2} \mathrm{DAB}\right)\left[\mathrm{Co}\left(\mathrm{H}_{2} \mathrm{PO}_{3}\right)_{4}\right] \cdot 2 \mathrm{H}_{2} \mathrm{O}$.

Author Contributions: Investigation, N.H., S.C., I.d.S., M.E. and R.A.; Project Administration, B.E.B.; Supervision, M.L., C.J. and B.E.B.; Visualization, I.d.S., R.A. and B.E.B.; Writing-Original Draft, N.H., S.C. and I.d.S.; Writing-Review and Editing, A.Y.A. and B.E.B. All authors have read and agreed to the published version of the manuscript.

Funding: This research had no external funding.

Institutional Review Board Statement: Not applicable.

Informed Consent Statement: Not applicable.

Data Availability Statement: All the data generated from this study are available upon request. Please contact the corresponding author.

Acknowledgments: The authors would like to acknowledge the support and technical assistance of Interface Regional University Center (Sidi Mohammed Ben Abdellah University, Fez) and the National Center for Scientific and Technical Research (CNRST-Rabat). Alhasan would like to acknowledge Afraa Razouk, Dahye Kim, and Hyemin Oh from Ewha Womans University (South Korea) for their assistance in the biological activity testes. We extend our gratitude to all members of the Academiacs International and Pharmasophy networks (https:/ / academiacs.eu/, accessed on 10 October 2022).

Conflicts of Interest: The authors declare no conflict of interest.

\section{References}

1. Dey, C.; Kundu, T.; Biswal, B.P.; Mallick, A.; Banerjee, R. Crystalline Metal-Organic Frameworks (MOFs): Synthesis, Structure and Function. Acta Cryst B 2014, 70, 3-10. [CrossRef]

2. García-Fernández, A.; Bermúdez-García, J.M.; Castro-García, S.; Artiaga, R.; López-Beceiro, J.; Señarís-Rodríguez, M.A.; SánchezAndújar, M. Dielectric Properties Induced by the Framework in the Hybrid Organic-Inorganic Compounds M(Dca)2pyz M=Fe, Co and Zn. Polyhedron 2016, 114, 249-255. [CrossRef]

3. Xiong, D.; Li, M.; Liu, W.; Chen, H.; Yang, X.; Zhao, J. Synthesis, Structure and Luminescence Property of Two Lanthanum Phosphite Hydrates: $\mathrm{La}_{2}\left(\mathrm{H}_{2} \mathrm{O}\right) \times\left(\mathrm{HPO}_{3}\right)_{3}(\mathrm{x}=1,2)$. J. Solid State Chem. 2006, 179, 2571-2577. [CrossRef]

4. Hamdi, N.; Hidaoui, S.; Hassani, H.O.; Lachkar, M.; Dusek, M.; Morley, N.; El Bali, B. Synthesis, Crystal Structure, Physical and Catalytic Oxidation Studies of a New Hybrid Phosphate $\left[\left(\mathrm{N}_{2} \mathrm{H}_{5}\right)_{2} \mathrm{Co}\left(\mathrm{HPO}_{4}\right)_{2}\right]$. J. Mol. Struct. 2020, 1217, 128317. [CrossRef]

5. Shen, M.; Forghani, F.; Kong, X.; Liu, D.; Ye, X.; Chen, S.; Ding, T. Antibacterial Applications of Metal-Organic Frameworks and Their Composites. Compr. Rev. Food Sci. Food Saf. 2020, 19, 1397-1419. [CrossRef]

6. Karimi Alavijeh, R.; Beheshti, S.; Akhbari, K.; Morsali, A. Investigation of Reasons for Metal-Organic Framework's Antibacterial Activities. Polyhedron 2018, 156, 257-278. [CrossRef]

7. Havlin, J.L.; Schlegel, A.J. Review of Phosphite as a Plant Nutrient and Fungicide. Soil Syst. 2021, 5, 52. [CrossRef]

8. Davis, M.E. Ordered Porous Materials for Emerging Applications. Nature 2002, 417, 813-821. Available online: https://www. nature.com/articles/nature00785 (accessed on 10 October 2021). [CrossRef]

9. Agarwal, R.A.; Mukherjee, S. One Dimensional Coordination Polymers of Cd (II) and Zn (II): Synthesis, Structure, Polar Packing through Strong Inter-Chain Hydrogen Bonding and Gas Adsorption Studies. Polyhedron 2016, 106, 163-170. [CrossRef]

10. Bakuru, V.R.; DMello, M.E.; Kalidindi, S.B. Metal-Organic Frameworks for Hydrogen Energy Applications: Advances and Challenges. ChemPhysChem 2019, 20, 1177-1215. [CrossRef]

11. Horcajada, P.; Gref, R.; Baati, T.; Allan, P.K.; Maurin, G.; Couvreur, P.; Férey, G.; Morris, R.E.; Serre, C. Metal-Organic Frameworks in Biomedicine. Chem. Rev. 2012, 112, 1232-1268. [CrossRef]

12. Chen, Z.; Li, X.; Yang, C.; Cheng, K.; Tan, T.; Lv, Y.; Liu, Y. Hybrid Porous Crystalline Materials from Metal Organic Frameworks and Covalent Organic Frameworks. Adv. Sci. 2021, 8, 2101883. [CrossRef] [PubMed]

13. Pettinari, C.; Pettinari, R.; di Nicola, C.; Tombesi, A.; Scuri, S.; Marchetti, F. Antimicrobial MOFs. Coord. Chem. Rev. 2021, 446, 214121. Available online: https://www.sciencedirect.com/science/article/abs/pii/S0010854521003957 (accessed on 10 October 2021). [CrossRef] 
14. Aguilar, C.A.H.; Jiménez, A.B.P.; Silva, A.R.; Kaur, N.; Thangarasu, P.; Ramos, J.M.V.; Singh, N. Organic-Inorganic Hybrid Nanoparticles for Bacterial Inhibition: Synthesis and Characterization of Doped and Undoped ONPs with Ag/Au NPs. Molecules 2015, 20, 6002-6021. [CrossRef] [PubMed]

15. Ouarsal, R.; Tahiri, A.A.; Bali, B.E.; Lachkar, M.; Bolte, M. Strontium Di hydrogenphosphite. Acta Crystallogr. Sect. E 2002, 58, i19-i20. [CrossRef]

16. Ouarsal, R.; Alaoui Tahiri, A.; Lachkar, M.; Slimani, Z.; El Bali, B.; Bolte, M. Barium Di hydrogen Phosphite Hemihydrate. Acta Crystallogr. E 2002, 58, i72-i73. [CrossRef]

17. Chaouche, S.; Ouarsal, R.; Bali, B.E.; Lachkar, M.; Bolte, M.; Dusek, M. $\mathrm{Li}_{2} \mathrm{HPO}_{3}, \mathrm{H}_{2} \mathrm{O}$ : Crystal Structure and IR Spectrum. J. Chem. Cryst. 2010, 40, 526-530. [CrossRef]

18. Chaouch, S.; Ouarsal, R.; Akouibaa, M.; Rakib, S.; Lachkar, M.; Bali, B.E.; Dusek, M. $\mathrm{Cs}_{2}\left[\mathrm{M}_{(}\left(\mathrm{H}_{2} \mathrm{O}\right)_{6}\right]_{3}\left(\mathrm{HPO}_{3}\right)_{4}, \mathrm{M}=\mathrm{Co}, \mathrm{Ni}$ : Crystal Structures, IR and Thermal Studies. J. Phys. Conf. Ser. 2018, 984, 012015. [CrossRef]

19. Ouarsal, R.; Tahiri, A.A.; El Bali, B.; Lachkar, M.; Harrison, W.T.A. Sodium Zinc Tris (Di hydrogenphosphite) Hydrate, $\mathrm{NaZn}\left(\mathrm{H}_{2} \mathrm{PO}_{3}\right)_{3} \cdot \mathrm{H}_{2} \mathrm{O}$. Acta Crystallogr. E 2002, 58, i23-i25. [CrossRef]

20. Ouarsal, R.; Alaoui Tahiri, A.; Lachkar, M.; Dusek, M.; Fejfarová, K.; El Bali, B. Sodium Magnesium Tris (Di hydrogen phosphite) Monohydrate, $\mathrm{NaMg}\left(\mathrm{H}_{2} \mathrm{PO}_{3}\right)_{3} \cdot \mathrm{H}_{2} \mathrm{O}$. Acta Crystallogr. Sect. E 2003, 59, i33-i35. [CrossRef]

21. Ouarsal, R.; Essehli, R.; Lachkar, M.; Zenkouar, M.; Dusek, M.; Fejfarova, K.; El Bali, B. Dipotassium Cobalt(II) Bis (Hydrogenphosphite) Dihydrate, $\mathrm{K}_{2} \mathrm{Co}\left(\mathrm{HPO}_{3}\right)_{2} \cdot 2 \mathrm{H}_{2} \mathrm{O}$. Acta Crystallogr. E 2004, 60, i66-i68. [CrossRef]

22. Messouri, I.; El Bali, B.; Capitelli, F.; Piniella, J.F.; Lachkar, M.; Slimani, Z. Diammonium Tris [Hexa aqua magnesium(II)] Tetra kis [Hydrogenphosphate(III)], (NH4) $)_{2}\left[\mathrm{Mg}\left(\mathrm{H}_{2} \mathrm{O}\right)_{6}\right]_{3}\left(\mathrm{HPO}_{3}\right)_{4}$. Acta Crystallogr. E 2005, 61, i129-i131. [CrossRef]

23. Ouarsal, R.; El Bali, B.; Lachkar, M.; Dusek, M.; Fejfarova, K. Diammonium Tris [Hexa aqua nickel(II)] Tetra kis [Hydrogenphosphate(III)], $\left(\mathrm{NH}_{4}\right)_{2}\left[\mathrm{Ni}\left(\mathrm{H}_{2} \mathrm{O}\right)_{6}\right]_{3}\left(\mathrm{HPO}_{3}\right)_{4}$. Acta Crystallogr. Sect. E 2005, 61, i171-i173. [CrossRef]

24. Ouarsal, R.; El Bali, B.; Lachkar, M.; Dusek, M.; Fejfarova, K. Diammonium Tris [Hexa aqua cobalt(II)] Tetra kis [Hydrogenphosphate(III)], (NH4) $)_{2}\left[\mathrm{Co}\left(\mathrm{H}_{2} \mathrm{O}\right)_{6}\right]_{3}\left(\mathrm{HPO}_{3}\right)_{4}$. Acta Crystallogr. E 2005, 61, i168-i170. [CrossRef]

25. Ouarsal, R.; Lachkar, M.; Dusek, M.; Albert, E.B.; Carda Castelló, J.B.; El Bali, B. Crystal Structure of $\mathrm{NaCd}_{2}\left(\mathrm{H}_{2} \mathrm{PO}_{3}\right)_{3} \cdot \mathrm{H}_{2} \mathrm{O}$ and Spectroscopic Study of $\mathrm{NaM}\left(\mathrm{H}_{2} \mathrm{PO}_{3}\right)_{3} \cdot \mathrm{H}_{2} \mathrm{O}, \mathrm{M}=\mathrm{Mn}, \mathrm{Co}, \mathrm{Ni}, \mathrm{Zn}, \mathrm{Mg}$ and Cd. Polyhedron 2016, 106, 132-137. [CrossRef]

26. Chaouche, S.; Ouarsal, R.; Lachkar, M.; Capitelli, F.; El Bali, B. Crystal Structure and IR Study of $\left(\mathrm{C}_{6} \mathrm{H}_{5} \mathrm{NH}_{3}\right)\left[\mathrm{ZnCl}\left(\mathrm{HPO}_{3}\right)\right]$. J Chem. Cryst. 2010, 40, 486-490. [CrossRef]

27. Liu, Y.; Xu, X.; Xia, Q.; Yuan, G.; He, Q.; Cui, Y. Multiple Topological Isomerism of Three-Connected Networks in Silver-Based Metal-Organoboron Frameworks. Chem. Commun. 2010, 46, 2608-2610. [CrossRef]

28. Zhuang, W.; Yuan, D.; Li, J.-R.; Luo, Z.; Zhou, H.-C.; Bashir, S.; Liu, J. Highly Potent Bactericidal Activity of Porous Metal-Organic Frameworks. Adv. Healthc. Mater. 2012, 1, 225-238. [CrossRef]

29. Rigaku Corporation. CrysAlisPro Software System; Rigaku Corporation: Oxford, UK, 2015.

30. Dolomanov, O.V.; Bourhis, L.J.; Gildea, R.J.; Howard, J.A.; Puschmann, H. OLEX2: A Complete Structure Solution, Refinement and Analysis Program. J. Appl. Crystallogr. 2009, 42, 339-341. [CrossRef]

31. Bourhis, L.J.; Dolomanov, O.V.; Gildea, R.J.; Howard, J.A.; Puschmann, H. The Anatomy of a Comprehensive Constrained, Restrained Refinement Program for the Modern Computing Environment-Olex2 Dissected. Acta Crystallogr. Sect. A Found. Adv. 2015, 71, 59-75. [CrossRef]

32. Diamond-Crystal and Molecular Structure Visualization, Crystal Impact-Dr. H. Putz \& Dr. K. Brandenburg GbR, Kreuzherrenstr. 102, 53227 Bonn, Germany. Available online: https:/ / www.crystalimpact.de/diamond (accessed on 10 October 2021).

33. Macrae, C.F.; Bruno, I.J.; Chisholm, J.A.; Edgington, P.R.; McCabe, P.; Pidcock, E.; Rodriguez-Monge, L.; Taylor, R.; Streek, J.V.D.; Wood, P.A. Mercury CSD 2.0-New Features for the Visualization and Investigation of Crystal Structures. J. Appl. Crystallogr. 2008, 41, 466-470. [CrossRef]

34. Mandal, S.; Natarajan, S. Inorganic-organic hybrid structure: Synthesis, structure and magnetic properties of a cobalt phosphiteoxalate, $\left[\mathrm{C}_{4} \mathrm{~N}_{2} \mathrm{H}_{12}\right]\left[\mathrm{Co}_{4}\left(\mathrm{HPO}_{3}\right)_{2}\left(\mathrm{C}_{2} \mathrm{O}_{4}\right)_{3}\right]$. J. Solid State Chem. 2005, 178, 2376-2382. [CrossRef]

35. Fernández, S.; Pizarro, J.L.; Mesa, J.L.; Lezama, L.; Arriortua, M.I.; Rojo, T. Hydrothermal Synthesis of a New Layered InorganicOrganic Hybrid Cobalt(II) Phosphite: $\left(\mathrm{C}_{2} \mathrm{H}_{10} \mathrm{~N}_{2}\right)\left[\mathrm{Co}_{3}\left(\mathrm{HPO}_{3}\right)_{4}\right]$ : Crystal Structure and Spectroscopic and Magnetic Properties. Int. J. Inorg. Mater. 2001, 3, 331-336. [CrossRef]

36. Liu, X.; Xing, Y.; Liu, X. Solvothermal Synthesis and Magnetic Properties of Cobalt (II) Phosphite Structures of Varying Dimensionality. CrystEngComm 2010, 12, 383-386. [CrossRef]

37. Li, J.; Li, T.; Zeng, H.; Zou, G.; Lin, Z. Solvent-Free Synthesis of Inorganic-Organic Hybrid Solids with Chainlike, Layered, and Open-Framework Structures. Inorg. Chem. Commun. 2018, 95, 8-11. [CrossRef]

38. Kantarc1, Z.; Sağlam, S.; Kasap, E. Vibrational Spectroscopic Studies On The 1,4-Diaminobutane-Td-Type Clathrates: $\mathrm{Cd}(\mathrm{Dabn}) \mathrm{M}(\mathrm{CN})_{4} 1,5 \mathrm{C}_{6} \mathrm{H}_{6}(\mathrm{M}=\mathrm{Cd}$ or Hg). Spectrosc. Lett. 2002, 35, 811-819. [CrossRef]

39. Aguado, S.; Quirós, J.; Canivet, J.; Farrusseng, D.; Boltes, K.; Rosal, R. Antimicrobial Activity of Cobalt Imidazolate Metal-Organic Frameworks. Chemosphere 2014, 113, 188-192. Available online: https://www.sciencedirect.com/science/article/abs / pii/S00456 53514006638 (accessed on 10 October 2021). [CrossRef] [PubMed] 
40. Xie, B.-P.; Chai, J.-W.; Fan, C.; Ouyang, J.-H.; Duan, W.-J.; Sun, B.; Chen, J.; Yuan, L.-X.; Xu, X.-Q.; Chen, J.-X. Water-Stable Silver-Based Metal-Organic Frameworks of Quaternized Carboxylates and Their Antimicrobial Activity. ACS Appl. Bio Mater. 2020, 3, 8525-8531. Available online: https://pubs.acs.org/doi/abs/10.1021/acsabm.0c00896 (accessed on 10 October 2021). [CrossRef] [PubMed]

41. Rodríguez, H.S.; Hinestroza, J.P.; Ochoa-Puentes, C.; Sierra, C.A.; Soto, C.Y. Antibacterial Activity against Escherichia Coli of Cu-BTC (MOF-199) Metal-organic Framework Immobilized onto Cellulosic Fibers. J. Appl. Polym. Sci. 2014, 131. Available online: https:/ / onlinelibrary.wiley.com/doi/abs/10.1002/app.40815 (accessed on 10 October 2021). [CrossRef]

42. Mao, K.; Zhu, Y.; Rong, J.; Qiu, F.; Chen, H.; Xu, J.; Yang, D.; Zhang, T.; Zhong, L. Rugby-Ball like Ag Modified Zirconium Porphyrin Metal-Organic Frameworks Nanohybrid for Antimicrobial Activity: Synergistic Effect for Significantly Enhancing Photoactivation Capacity. Colloids Surf. A Physicochem. Eng. Asp. 2021, 611, 125888. [CrossRef]

43. Yang, S.; Peng, L.; Oveisi, E.; Bulut, S.; Sun, D.T.; Asgari, M.; Trukhina, O.; Queen, W.L. MOF-Derived Cobalt Phosphide/Carbon Nanocubes for Selective Hydrogenation of Nitroarenes to Anilines. Chem. A Eur. J. 2018, 24, 4234-4238. Available online: https:/ / chemistry-europe.onlinelibrary.wiley.com/doi/abs/10.1002/chem.201705400 (accessed on 10 October 2021). [CrossRef] [PubMed]

44. Xia, G.; Su, J.; Li, M.; Jiang, P.; Yang, Y.; Chen, Q. A MOF-Derived Self-Template Strategy toward Cobalt Phosphide Electrodes with Ultralong Cycle Life and High Capacity. J. Mater. Chem. A 2017, 5, 10321-10327. [CrossRef]

45. Hou, C.-C.; Zou, L.; Wang, Y.; Xu, Q. MOF-Mediated Fabrication of a Porous 3D Superstructure of Carbon Nanosheets Decorated with Ultrafine Cobalt Phosphide Nanoparticles for Efficient Electrocatalysis and Zinc-Air Batteries. Angew. Chem. 2020, 132, 21544-21550. [CrossRef]

46. Irgi, E.P.; Geromichalos, G.D.; Balala, S.; Kljun, J.; Kalogiannis, S.; Papadopoulos, A.; Turel, I.; Psomas, G. Cobalt(II) Complexes with the Quinolone Antimicrobial Drug Oxolinic Acid: Structure and Biological Perspectives. RSC Adv. 2015, 5, 36353-36367. [CrossRef]

47. Wu, R.; Wang, D.P.; Zhou, K.; Srikanth, N.; Wei, J.; Chen, Z. Porous Cobalt Phosphide/Graphitic Carbon Polyhedral Hybrid Composites for Efficient Oxygen Evolution Reactions. J. Mater. Chem. A 2016, 4, 13742-13745. [CrossRef]

48. Chang, E.L.; Simmers, C.; Knight, D.A. Cobalt Complexes as Antiviral and Antibacterial Agents. Pharmaceuticals 2010, 3, 1711-1728. [CrossRef]

49. Hatamie, S.; Nouri, M.; Karandikar, S.K.; Kulkarni, A.; Dhole, S.D.; Phase, D.M.; Kale, S.N. Complexes of Cobalt Nanoparticles and Polyfunctional Curcumin as Antimicrobial Agents. Mater. Sci. Eng. C 2012, 32, 92-97. [CrossRef]

50. Dorkov, P.; Pantcheva, I.N.; Sheldrick, W.S.; Mayer-Figge, H.; Petrova, R.; Mitewa, M. Synthesis, Structure and Antimicrobial Activity of Manganese(II) and Cobalt(II) Complexes of the Polyether Ionophore Antibiotic Sodium Monensin A. J. Inorg. Biochem. 2008, 102, 26-32. [CrossRef]

51. Alahmadi, N.S.; Betts, J.W.; Cheng, F.; Francesconi, M.G.; Kelly, S.M.; Kornherr, A.; Prior, T.J.; Wadhawan, J.D. Synthesis and Antibacterial Effects of Cobalt-Cellulose Magnetic Nanocomposites. RSC Adv. 2017, 7, 20020-20026. [CrossRef]

52. Dey, K.; Maiti, R.K.; Bhar, J.K.; Banerjee, R.D.; Sarkar, G.M.; Malakar, A.; Datta, S.; Banerjee, P. Antimicrobial, Insect Sterilizing and Ovicidal Activity of Some Cobalt(II) and Cobalt(III) Complexes. Agents Actions 1981, 11, 762-769. Available online: https:/ /link.springer.com/article/10.1007/BF01978802 (accessed on 10 October 2021). [CrossRef] 